\title{
Multifaceted Defense against Listeria monocytogenes in the Gastro-Intestinal Lumen
}

\author{
Simone Becattini ${ }^{1, *}$ and Eric G. Pamer ${ }^{1,2,3, *}$ \\ 1 Immunology Program, Sloan Kettering Institute, Memorial Sloan-Kettering Cancer Center, \\ New York, NY 10065, USA \\ 2 Lucille Castori Center for Microbes Inflammation and Cancer, Molecular Microbiology Core Facility, \\ Memorial Sloan-Kettering Cancer Center, New York, NY 10065, USA \\ 3 Infectious Diseases Service, Department of Medicine, Memorial Sloan-Kettering Cancer Center, \\ New York, NY 10065, USA \\ * Correspondence: becattis@mskcc.org (S.B.); pamere@mskcc.org (E.G.P.)
}

Received: 1 December 2017; Accepted: 20 December 2017; Published: 22 December 2017

\begin{abstract}
Listeria monocytogenes is a foodborne pathogen that can cause febrile gastroenteritis in healthy subjects and systemic infections in immunocompromised individuals. Despite the high prevalence of L. monocytogenes in the environment and frequent contamination of uncooked meat and poultry products, infections with this pathogen are relatively uncommon, suggesting that protective defenses in the general population are effective. In the mammalian gastrointestinal tract, a variety of defense mechanisms prevent $L$. monocytogenes growth, epithelial penetration and systemic dissemination. Among these defenses, colonization resistance mediated by the gut microbiota is crucial in protection against a range of intestinal pathogens, including L. monocytogenes. Here we review defined mechanisms of defense against $L$. monocytogenes in the lumen of the gastro-intestinal tract, with particular emphasis on protection conferred by the autochthonous microbiota. We suggest that selected probiotic species derived from the microbiota may be developed for eventual clinical use to enhance resistance against $L$. monocytogenes infections.
\end{abstract}

Keywords: Listeria monocytogenes; microbiota; colonization resistance

\section{Introduction}

Listeria monocytogenes is a gram-positive pathogen that infects humans and animals by ingestion of contaminated food, and is associated with high rates of mortality [1,2]. While Listeria outbreaks are common and generally attributable to highly contaminated foods, most cases of listeriosis are sporadic [3].

From the intestinal lumen, L. monocytogenes can cross the epithelial layer via a variety of mechanisms, including receptor-dependent entry into Goblet and epithelial cells, as well as trancytosis through $\mathrm{M}$ cells and penetration into underlying tissues [4-11]. Systemic spread of L. monocytogenes can have particularly severe consequences for selected cohorts of individuals, such as immunocompromised and cancer patients, pregnant women, young children and the elderly [1,2]. If ingested at high doses, L. monocytogenes can also induce febrile gastro-enteritis in healthy individuals $[12,13]$. High pathogen load in food is generally the result of contamination that occurs in food-manufacturing plants (cheese, packaged meat, pre-washed and pre-sliced processed produce), which is mainly due to L. monocytogenes dispersion in livestock and the environment. Several studies have identified L. monocytogenes in feces of a high percentage of dairy and beef cattle and in sheep [14-16]. Furthermore, L. monocytogenes is commonly found in sewage sludge [17], which is occasionally used to fertilize agricultural land. Thus, L. monocytogenes is widely distributed in the 
environment and frequently contaminates foods, making encounter with this pathogen a relatively common event for humans.

Although it is not widely appreciated, Listeria monocytogenes transiently and asymptomatically colonizes a sizable percentage of the human population, with estimates varying between 1 and $5 \%$ across studies $[15,18-23]$. The frequency of colonization with L. monocytogenes exceeds the reported incidence of Listeriosis by orders of magnitude [2,3]. This discrepancy might be the result of undiagnosed cases of Listeriosis, as symptoms of the infection can be mild and resolve spontaneously, making blood culturing and hospital admission unnecessary, particularly with respect to the L. monocytogenes-induced enteritis. Furthermore, ad hoc detection tests for L. monocytogenes are not routinely performed in hospitalized subjects, as suggested elsewhere [24,25]. However, a more likely possibility is that despite frequent passages through the GI tract of human beings, L. monocytogenes rarely progresses to systemic infection. This would suggest that efficient resistance mechanisms are in place to prevent expansion of this pathogen following ingestion. Among other factors, the presence of a healthy gut microbiota, which can provide colonization resistance against a variety of enteric pathogens, may be particularly effective. Here we review evidence from studies conducted over the past five decades that support a key role for host-derived as well as commensal microbe-associated factors in providing protection against intestinal colonization and systemic infection with Listeria monocytogenes.

\section{A Brief Overview of In Vivo Colonization by L. monocytogenes}

The mechanisms of Listeria invasion and spread within the mammalian host have been elucidated by elegant experimental studies mapping the trafficking of genetically tagged bacteria upon inoculation into mice and guinea pigs $[26,27]$. These studies have demonstrated that $L$. monocytogenes replicates in intestinal villi and is shed into the gut lumen, generating a second wave of penetration that results in Peyer's Patch invasion. Subsequently, L. monocytogenes accesses mesenteric lymph nodes and disseminates to spleen and liver, also colonizing the gallbladder. L. monocytogenes replicates in the gallbladder and re-accesses the intestinal lumen via the common bile duct upon gallbladder contraction [26,27].

Although most studies have focused on L. monocytogenes colonization and invasion of the small intestine, several studies, including our own, have demonstrated that marked expansion and prolonged persistence of L. monocytogenes occurs in the large intestine of rodents as well as other model animals [10,28-30]. Thus, the large intestine, rather than the small intestine, may be the major portal of dissemination for L. monocytogenes, consistent with the high local density of Goblet cells, which have been shown to be permissive for pathogen trans-cytosis [31]. Intra-rectal administration of Listeria results in systemic infection of mice following dissemination via caudal lymph nodes [29,32], supporting the notion that the large intestine serves as a likely invasion portal.

\section{Defense against Listeria monocytogenes in the Gastro-Intestinal Lumen}

\subsection{Host-Derived Factors}

\subsubsection{Host Physical and Chemical (Non-Immune) Defenses}

Mice and humans are overall highly resistant to L. monocytogenes infection via the oral route [33]. This is likely due to a variety of factors, including the presence of multiple lines of defense along the host's GI tract. To begin with, there are a number of physical and chemical defenses that the gastrointestinal milieu engages against foodborne pathogens, and in response to which L. monocytogenes expresses an array of molecular weapons, extensively reviewed elsewhere [34]. Activation of dedicated stress responses in Listeria, which allow bacterial survival in the intestinal lumen, results from the enlistment of the alternative RNA polymerase factor SigB and on the virulence regulator prfA, both of which are induced upon passage through the mammalian GI tract $[35,36]$. 
Briefly, upon ingestion and transit to the stomach and duodenum, L. monocytogenes is first exposed to low $\mathrm{pH}$ gastric acids, whose bactericidal activity is potent with respect to this particular pathogen [36]. Accordingly, both humans and animals appear to have increased susceptibility to infection upon treatment with drugs that reduce gastric acidity $[37,38]$. As a result of gastric acid-mediated killing of L. monocytogenes, only a fraction of the infectious inoculum enters the small intestine of laboratory animals in the minutes to hours following the infection [39], providing at least a partial explanation for the need to use high doses of L. monocytogenes to induce disease in healthy individuals. Importantly, L. monocytogenes undergoes a "stress hardening" response in that exposure to moderately low $\mathrm{pH}(\sim 5.5)$ increases its resistance to otherwise lethal $\mathrm{pH}(\sim 3.5)$ [34]. This process was shown to increase viability of the pathogen in vivo after oral inoculation, including favoring spread of live bacteria to the mesenteric lymph nodes [40]. Resistance against low $\mathrm{pH}$ in the stomach and duodenum is achieved by L. monocytogenes through several mechanisms, including import and decarboxylation of glutamate and catabolism of arginine to ornithine, both resulting in consumption of protons and increases in intracellular $\mathrm{pH}$ [41-43].

Upon passage to the duodenum, Listeria also utilizes several transporters to resist osmotic stress, as salt concentration in the intestine is relatively high [34]. Bile salts also represent a defensive antibacterial mechanism that protects the host by preventing expansion of certain pathogens [44-46]. Listeria, however, can grow directly in the gallbladder of humans and mice, in the presence of high concentrations of bile salts [47], and re-enter the intestinal lumen via the bile duct [48]. The high levels of resistance to bile are, in part, conferred by expression of bile-salts hydrolases, which are up-regulated in hypoxic conditions [49-51], as well as bile exclusion systems [52,53].

To persist in the gut, L. monocytogenes must at least partially resist expulsion by intestinal peristalsis. Adhesion to the intestinal epithelium enables L. monocytogenes to delay expulsion and is regulated by the virulence factor ActA [54] and the adhesion protein LAP [55], among others. In order to disseminate from the gut, L. monocytogenes must overcome the physical barriers represented by the mucus layer and the intestinal epithelium, respectively [56]. Several proteins encoded by the genome of Listeria isolates, including internalins, have been shown to bind host mucins, and might therefore be involved in adherence to the mucus layer [57-59]. Listeriolysin O (LLO), the major virulence factor secreted by L. monocytogenes that enables it to access the cytoplasm of infected cells, can compromise barrier functions of epithelial monolayers [60]. Interestingly, epithelial cells respond to exposure to LLO by increasing mucin production, thereby reinforcing the barrier against $L$. monocytogenes invasion [61,62]. Intestinal P glycoprotein also provides a defense against $L$. monocytogenes infection, through mechanisms that remain to be elucidated, and mice lacking this protein show higher bacterial dissemination following oral challenge [63].

\subsubsection{Host Immune Defenses}

Multiple immune mechanisms also contribute to reducing L. monocytogenes density in the gastro-intestinal lumen. Although mucosal antibodies are produced in response to L. monocytogenes infection [64], these are mostly not protective, and intestinal clearance of Listeria occurs with similar kinetics in WT and Rag-deficient mice, thus ruling out a prominent role for immunoglobulins in pathogen expulsion [28]. In contrast, innate immune mechanisms have been consistently reported to effectively reduce L. monocytogenes expansion in the gut lumen. One of the most studied among such mechanisms is production of anti-bacterial peptides by Paneth and epithelial cells. RegIII $\gamma$ is a bactericidal lectin whose production is induced by microbial stimuli, via signaling through the adaptor protein MyD88 and production of IL-23 and IL-22 [39,65]. Using a mouse model utilizing ileal loop ligation, RegIII $\gamma$ was shown to kill L. monocytogenes in the small intestinal lumen [39]. More recent studies have demonstrated that proteins of the RegIII family form a pore in the bacterial cell membrane [66]. Crypdtidins (called $\alpha$-defensins in humans) are anti-microbial peptides produced in the intestine, in a partially NOD2 dependent manner. Although absence of NOD2 signaling reduces expression of some cryptidins and increases susceptibility to systemic L. monocytogenes infection 
following intra-gastric inoculation, it is unclear whether this involves enhanced bacterial growth in the intestinal lumen [67]. Along similar lines, a porcine $\beta$-defensin homologous to human $\beta$-defensin 1 was found to have anti-Listerial activity in vitro [68], and similar results were obtained with intestinal phospholipase A2 (iPLA2) [69].

The antimicrobial peptide CRAMP, which protects the intestinal compartment during early life prior to the development of Paneth cells, increases resistance to orally inoculated Listeria [70]. Of note, Paneth cell-secreted anti-microbial peptides are only effective in close proximity to the crypt or within the mucus layer, but not in the intestinal lumen [71]. It is likely, therefore, that other mechanisms prevent uncontrolled growth of L. monocytogenes in the intestinal lumen.

\subsection{Gut Microbiota}

\subsubsection{Evidences for a Role of Gut Microbiota in Protection against Listeria monocytogenes}

The intestinal microbiota can directly and indirectly influence most of the protective immune mechanisms mentioned above, by providing tonic signals to the host's mucosal epithelial cells and the innate and adaptive immune systems. For instance, production of mucus [72] and anti-microbial peptides [73], modification of conjugated primary bile salts [74], hematopoiesis [75] and functional maturation of immune cells [76], are all heavily influenced by gut commensal bacteria (reviewed in [77]). The protective role of commensal bacteria has been demonstrated in the setting of gastrointestinal L. monocytogenes infection. For example, commensal bacteria are necessary for correct cargo sorting in Paneth cells, and depletion of microbiota through antibiotic treatment results in lysosomal degradation of lysozyme, which increases both intestinal and systemic invasion of Listeria monocytogenes [78]. The microbiota also induces up-regulation of the surface molecule SLAM4 selectively on intestinal lymphocytes, and this promotes resistance to oral challenge with Listeria monocytogenes [79]. Some Lactobacilli have been shown to modulate host immune responses in the intestine, leading to a small but significant reduction in the expansion and dissemination of orally inoculated Listeria [80]. Similarly it was shown that, in vitro, Lactobacilli and Bifidobacteria can prevent Listeria invasion of epithelial cells, both by secreting anti-bacterial factors, as well as by modulating epithelial cytokine production [81].

Aside from these indirect effects on host metabolism and immune development, the microbiota provides direct colonization resistance against exogenously acquired bacteria. Indeed, colonization resistance represents arguably the most important benefit that the host derives from its symbiosis with commensal bacteria [82]. Classical experiments from more than 60 years ago demonstrated that antibiotic-mediated depletion of the microbiota markedly enhances susceptibility to bacterial (Salmonella) infections [83]. However, only in recent years have the underlying mechanisms been elucidated. It is now appreciated that different bacterial species provide resistance to specific pathogens through distinct mechanisms. Thus, antibiotics with distinct antibacterial spectra can differ in terms of inducing susceptibility to colonization and infection with different pathogens $[44,84]$.

L. monocytogenes is also vulnerable to microbiota-mediated colonization resistance and commensal microbes can be highly effective at reducing its expansion in the intestinal lumen. The first demonstration of this concept was provided by experiments comparing the efficiency and severity of oral L. monocytogenes infection in germ-free (GF) versus specific-pathogen free (SPF) rodents $[85,86]$. GF mice and rats, in contrast to animals bearing an intact autochthonous microbiota, were highly susceptible to extremely low doses of Listeria, [85,86]. Although suboptimal immune development in GF animals [87] might have contributed to these results, it is now appreciated that immune mechanisms are unlikely to completely mediate the dramatic inhibition of L. monocytogenes expansion in the gut lumen of SPF compared to GF animals (8-10 orders of magnitude) $[39,85,86]$. The early studies with GF animals correctly hypothesized that the microbiota plays a major, direct role in providing colonization resistance against $L$. monocytogenes.

Initial attempts to protect GF mice by transferring commensal Clostridium and a Bacteroides species prior to L. monocytogenes infection were only partially successful and demonstrated that the 
pathogen still expanded to high densities in the lumen, but that the number of bacteria near the intestinal mucus layer was reduced in the presence of these commensals [85]. Given the remarkable diversity of the "healthy" intestinal microbiota, the incomplete effectiveness of the two selected commensal bacterial strains likely reflects the requirement for additional bacterial species to provide complete protection. Indeed, swabbing the mouth of L. monocytogenes-monoassociated gnotobiotic rats with a suspension of feces from conventional SPF animals was sufficient to reduce Listeria luminal density by about seven orders of magnitude within a day, and to obtain complete pathogen clearance in a few weeks [86]. Further supporting a role for the microbiota in providing protection against intestinal L. monocytogenes infection, it was noted that prolonged starvation, which is known to perturb the composition of intestinal commensal communities, predisposes guinea pigs to listeriosis [85]. Along similar lines, a study in rats showed that a higher percentage of animals become infected upon pre-treatment with antibiotics [88]. Furthermore, treatment with cephalosporins (a class of eta-lactam antibiotics to which L. monocytogenes is resistant) was shown to worsen the effect of immune-suppressant drugs administered prior to oral L. monocytogenes inoculation, by increasing both intestinal expansion and systemic spread of intragastrically inoculated bacteria [89].

Consistent with this previous work, we recently showed that perturbation of the microbiota through antibiotic treatment dramatically increases luminal expansion of L. monocytogenes in mice, rendering doses as low as $100 \mathrm{CFUs}$ capable of colonizing the entire intestinal tract and leading to systemic spread [28]. Disruption of microbiota-mediated colonization resistance dramatically increased susceptibility of immunocompromised hosts, such as Rag/common $\gamma$ chain-deficient mice, which lack B, T and natural killer (NK) cells and innate lymphocytes (ILCs) to L. monocytogenes infection. Mice treated with anti-cancer chemotherapy and rendered leukopenic maintained resistance to low-dose oral L. monocytogenes infection unless the microbiota was disrupted with antibiotics, in which case there was a marked increase in bacterial dissemination from the gut leading to increased mortality. These immunocompromised mice succumbed to infection with Listeria inocula as low as $10^{4} \mathrm{CFUs}$, indicating that the in the absence of a functional immune system, the microbiota plays a non-redundant and critical protective role [28]. These findings are of clinical relevance, as immunocompromised patients can develop systemic L. monocytogenes infections that are sporadic, i.e., not associated with large outbreaks, and thus likely result from the ingestion of foods that are contaminated with relatively low densities of L. monocytogenes.

The intestinal content of mice efficiently suppresses growth of Listeria monocytogenes in anaerobic co-culture systems. This inhibition is complex in that supernatants of cultures of small intestinal content inhibit L. monocytogenes growth, while inhibition by colonic bacteria requires bacterial co-cultures and thus is not mediated by a secreted product [28]. This difference likely reflects the higher density of Lactobacilli in the small intestine, which produce bacteriocins capable of killing Listeria monocytogenes [90-93]. We recently identified bacterial taxa that provide colonization resistance against $L$. monocytogenes, and assembled a consortium of four Clostridiales species that efficiently protect ex-GF mice, upon reconstitution, from orally administered L. monocytogenes. In contrast, GF mice reconstituted with dysbiotic microbial consortia recovered from antibiotic-treated mice had marked luminal replication of L. monocytogenes with dissemination to the spleen and liver [28]. Since isolated bacterial strains and commensals from antibiotic-treated mice have also been shown to promote L. monocytogenes expansion [28,94], it is clear that the gut microbiota, depending on its composition, can increase resistance or enhance susceptibility to infection. Because dysbiosis can dramatically impact susceptibility to L. monocytogenes infection, we propose that in individuals at high risk for infection, gut microbiota composition might represent an important predisposing factor. Characteristics such as advanced age $[95,96]$, altered physiological status (for instance pregnancy) [97] and use of immunosuppressive medications [98] are known to alter the structure of commensal communities and are associated with increased susceptibility to listeriosis, raising the possibility that changes in the microbiota represent an underlying cause of this association. 
Recent work from a number of laboratories strongly suggests that commensal bacteria might be developed as probiotics that could facilitate the prevention or even treatment of gastrointestinal Listeriosis. Interestingly, colonization resistance against L. monocytogenes has likely been serendipitously exploited in the poultry industry, by the provision of commercially available competitive exclusion (CE) cultures, i.e., preparations of commensal bacteria from cecal contents of adult healthy broiler chickens [99]. Such products have been used successfully to prevent expansion of human pathogens (particularly Salmonella species) in the intestine of chickens in the poultry industry, with protection being provided by a handful of bacterial strains later identified through in vitro screenings [100]. As for L. monocytogenes, one study showed that when gavaged into young chickens prior to challenge, CE cultures prevented intestinal expansion of the pathogen in $100 \%$ of the cases [101].

3.2.2. Possible Mechanisms Involved in Microbiota-Mediated Colonization Resistance against Listeria monocytogenes

Direct microbiota-mediated inhibition of Listeria monocytogenes can be potentially achieved through different mechanisms, of which the best studied is production of anti-microbial molecules. These include bacteriocins, mainly produced by the genera lactobacillus, lactococcus, enterococcus and bifidobacterium [102].

Many bacteriocins have been shown to be highly active against $L$. monocytogenes in vitro [90-93]. Importantly, multiple bacterial strains producing anti-listerial bacteriocins could be isolated from cultures of human stool, leading to the suggestion that those strains might be useful as probiotics to prevent or treat Listeriosis [103-106].

Lantibiotics are a class of bacteriocins/antibiotics that seem to be particularly effective against Listeria monocytogenes. Nisins, the prototypical lantibiotics, are produced by L. lactis and other commensals, and have been approved by the FDA (US Food and Drug Administration) as a food preservative [107]. The isotype nisin V, in particular, has pronounced anti-Listerial activity both in vitro and in vivo [108-110]. Formicin, another recently identified lantibiotic, also inhibits L. monocytogenes growth [111].

Although bacteriocin production correlates with in vitro Listeria inhibition, in vivo experiments demonstrating the efficacy of endogenous production of these molecules (i.e., intestinal reconstitution of model animals with protective strains) are for the most part lacking in the literature. One notable exception is the work of Gahan and collaborators, who showed that daily gavage with a Lactobacillus salivarius strain producing the Abp118 bacteriocin conferred resistance to Listeria infection in mice [112].

Bacterial soluble mediators other than bacteriocins have also been reported to be active against Listeria. Escherichia coli Nissle 1917, a probiotic strain that has been tested in clinical trials, prevents L. monocytogenes entry into intestinal cell lines, without affecting pathogen's viability, through a contact-independent mechanism [113].

Alternative soluble mediators of microbial origin that can protect against L. monocytogenes include short chain fatty acids [114]. Veillonellae were shown to inhibit L. monocytogenes in the presence of high concentrations of tartrate, which enhanced the production of propionate and acetate, thus decreasing the $\mathrm{pH}$ of the culture [115]. This suggests that diet could also affect the capacity of specific commensals to promote colonization resistance against $L$. monocytogenes.

Mechanisms of bacterial suppression of L. monocytogenes that do not rely on the release of soluble mediators might include nutrient competition and contact-dependent mechanisms. Contact dependent inhibition (CDI) mechanisms are known to operate among Gram negative bacterial species [116,117]. Although the existence of CDI in Gram+ bacteria, and in particular against Listeria monocytogenes, had been postulated based on experimental results $[28,118,119]$, no mechanism had been proposed until recently. Pioneering work from Mougous and collaborators has now definitively proven CDI to exist also among Gram positive bacteria, and has begun to reveal the molecular mechanisms [120]. Briefly, toxins of the LXG protein family can be produced by Gram positive bacteria and are translocated into neighboring Gram positive cells through the Esx transport system, where they promote degradation of lipid II and consequently inhibit peptidoglycan biosynthesis. Specific immunity genes provide 
resistance to these toxins in the producing strains. Importantly, this study identified LXG toxins as widely distributed across Firmicutes in the human intestinal microbiota, suggesting a potential role for these molecules not only in shaping the composition of the bacterial community, but possibly also in providing colonization resistance against Gram positive pathogens [120].

Of note, bacteria belonging to the Listeria genus encode CDI-mediating LXG toxins [121]. Furthermore, epidemic L. monocytogenes strains have been shown to carry Listeriolin S (LLS), which favors luminal expansion of the pathogen and tissue invasion, likely via elimination of competing commensals [122]. Thus, it appears that L. monocytogenes is endowed with a range of defenses to combat commensals and promote its own survival in the intestine.

\section{Conclusions}

Luminal expansion of L. monocytogenes in the gut increases the risk of systemic dissemination and the development of severe disease, and classic and more recent experimental studies using animal models are revealing that host defense is multifaceted, involving the epithelial barrier, innate and adaptive immune defenses and, perhaps least appreciated but extremely important, the commensal microbial populations that inhabit the mammalian GI tract. Protective mechanisms include the low $\mathrm{pH}$ and high osmolarity of gastric juices and intestinal content, bile acids, antimicrobial molecules of host origin and those produced by the autochtonous microbiota. The healthy gut microbiota utilizes multiple strategies to effectively reducing Listeria monocytogenes survival upon oral ingestion. We propose that microbiota-mediated colonization resistance represents the main mechanism by which hosts are rendered highly resistant to frequent encounters with L. monocytogenes. If this hypothesis were correct, two corollaries would be particularly relevant: first, subjects considered at risk should be spared as much as possible from microbiota-perturbing interventions; second, provision of specific probiotics might benefit highly susceptible individuals as well as the general population, especially during outbreaks of L. monocytogenes infection. Because intestinal commensal bacterial species are non-pathogenic and readily culturable, their use to prevent and possibly treat early phases of Listeria monocytogenes infection may have significant clinical utility. Of note, expanding on our work [28], it can be envisioned that a probiotic consortium composed by multiple commensal bacteria capable of inhibiting L. monocytogenes via distinct and synergistic mechanisms might provide high-level resistance to this pathogen.

Acknowledgments: This work was supported by grants from the National Institutes of Health (P30 CA008748; PO1 CA023766; RO1 AI095706; RO1 AI42135; UO1 AI124275) and a grant from Cycle for Survival to the MSK Center for Microbes, Inflammation and Cancer. SB is a Cancer Research Institute Irvington Fellow supported by the Cancer Research Institute.

Conflicts of Interest: The authors declare no conflict of interest.

\section{References}

1. Swaminathan, B.; Gerner-Smidt, P. The epidemiology of human listeriosis. Microbes Infect. Inst. Pasteur 2007, 9, 1236-1243. [CrossRef] [PubMed]

2. Vazquez-Boland, J.A.; Kuhn, M.; Berche, P.; Chakraborty, T.; Dominguez-Bernal, G.; Goebel, W.; Gonzalez-Zorn, B.; Wehland, J.; Kreft, J. Listeria pathogenesis and molecular virulence determinants. Clin. Microbiol. Rev. 2001, 14, 584-640. [CrossRef] [PubMed]

3. Centers for Disease Control and Prevention (CDC). Listeria Outbreaks. Available online: http://www.cdc. gov/listeria/outbreaks/index.html (accessed on 21 December 2017).

4. Lecuit, M. Understanding how listeria monocytogenes targets and crosses host barriers. Clin. Microbiol. Infect. 2005, 11, 430-436. [CrossRef] [PubMed]

5. Marco, A.J.; Altimira, J.; Prats, N.; Lopez, S.; Dominguez, L.; Domingo, M.; Briones, V. Penetration of listeria monocytogenes in mice infected by the oral route. Microb. Pathog. 1997, 23, 255-263. [CrossRef] [PubMed]

6. Pron, B.; Boumaila, C.; Jaubert, F.; Sarnacki, S.; Monnet, J.P.; Berche, P.; Gaillard, J.L. Comprehensive study of the intestinal stage of listeriosis in a rat ligated ileal loop system. Infect. Immun. 1998, 66, 747-755. [PubMed] 
7. MacDonald, T.T.; Carter, P.B. Cell-mediated immunity to intestinal infection. Infect. Immun. 1980, $28,516-523$. [PubMed]

8. Corr, S.; Hill, C.; Gahan, C.G. An in vitro cell-culture model demonstrates internalin- and hemolysin-independent translocation of listeria monocytogenes across $\mathrm{m}$ cells. Microb. Pathog. 2006, 41, 241-250. [CrossRef] [PubMed]

9. Chiba, S.; Nagai, T.; Hayashi, T.; Baba, Y.; Nagai, S.; Koyasu, S. Listerial invasion protein internalin b promotes entry into ileal peyer's patches in vivo. Microbiol. Immunol. 2011, 55, 123-129. [CrossRef] [PubMed]

10. Bou Ghanem, E.N.; Jones, G.S.; Myers-Morales, T.; Patil, P.D.; Hidayatullah, A.N.; D'Orazio, S.E. Inla promotes dissemination of listeria monocytogenes to the mesenteric lymph nodes during food borne infection of mice. PLoS Pathog. 2012, 8, e1003015. [CrossRef] [PubMed]

11. Jensen, V.B.; Harty, J.T.; Jones, B.D. Interactions of the invasive pathogens salmonella typhimurium, listeria monocytogenes, and shigella flexneri with $\mathrm{m}$ cells and murine peyer's patches. Infect. Immun. 1998, 66, 3758-3766. [PubMed]

12. Dalton, C.B.; Austin, C.C.; Sobel, J.; Hayes, P.S.; Bibb, W.F.; Graves, L.M.; Swaminathan, B.; Proctor, M.E.; Griffin, P.M. An outbreak of gastroenteritis and fever due to listeria monocytogenes in milk. N. Engl. J. Med. 1997, 336, 100-105. [CrossRef] [PubMed]

13. Aureli, P.; Fiorucci, G.C.; Caroli, D.; Marchiaro, G.; Novara, O.; Leone, L.; Salmaso, S. An outbreak of febrile gastroenteritis associated with corn contaminated by listeria monocytogenes. N. Engl. J. Med. 2000, 342, 1236-1241. [CrossRef] [PubMed]

14. Esteban, J.I.; Oporto, B.; Aduriz, G.; Juste, R.A.; Hurtado, A. Faecal shedding and strain diversity of listeria monocytogenes in healthy ruminants and swine in northern spain. BMC Vet. Res. 2009, 5, 2. [CrossRef] [PubMed]

15. Iida, T.; Kanzaki, M.; Nakama, A.; Kokubo, Y.; Maruyama, T.; Kaneuchi, C. Detection of listeria monocytogenes in humans, animals and foods. J. Vet. Med. Sci. 1998, 60, 1341-1343. [CrossRef] [PubMed]

16. Yokoyama, E.; Saitoh, T.; Maruyama, S.; Katsube, Y. The marked increase of listeria monocytogenes isolation from contents of swine cecum. Comp. Immunol. Microbiol. Infect. Dis. 2005, 28, 259-268. [CrossRef] [PubMed]

17. Garrec, N.; Picard-Bonnaud, F.; Pourcher, A.M. Occurrence oflisteriasp. Andl. Monocytogenesin sewage sludge used for land application: Effect of dewatering, liming and storage in tank on survival oflisteriaspecies. FEMS Immunol. Med. Microbiol. 2003, 35, 275-283. [CrossRef]

18. Kampelmacher, E.H.; van Noorle Jansen, L.M. Isolation of listeria monocytogenes from faeces of clinically healthy humans and animals. Zent. Bakteriol. Orig. 1969, 211, 353-359.

19. Cobb, C.A.; Curtis, G.D.; Bansi, D.S.; Slade, E.; Mehal, W.; Mitchell, R.G.; Chapman, R.W. Increased prevalence of listeria monocytogenes in the faeces of patients receiving long-term H2-antagonists. Eur. J. Gastroenterol. Hepatol. 1996, 8, 1071-1074. [CrossRef] [PubMed]

20. Grif, K.; Patscheider, G.; Dierich, M.P.; Allerberger, F. Incidence of fecal carriage of listeria monocytogenes in three healthy volunteers: A one-year prospective stool survey. Eur. J. Clin. Microbiol. Infect. Dis. 2003, 22, 16-20. [PubMed]

21. MacGowan, A.P.; Bowker, K.; McLauchlin, J.; Bennett, P.M.; Reeves, D.S. The occurrence and seasonal changes in the isolation of listeria spp. In shop bought food stuffs, human faeces, sewage and soil from urban sources. Int. J. Food Microbiol. 1994, 21, 325-334. [CrossRef]

22. Pinner, R.W.; Schuchat, A.; Swaminathan, B.; Hayes, P.S.; Deaver, K.A.; Weaver, R.E.; Plikaytis, B.D.; Reeves, M.; Broome, C.V.; Wenger, J.D. Role of foods in sporadic listeriosis. Ii. Microbiologic and epidemiologic investigation. The listeria study group. JAMA 1992, 267, 2046-2050. [CrossRef] [PubMed]

23. Schuchat, A.; Deaver, K.A.; Wenger, J.D.; Plikaytis, B.D.; Mascola, L.; Pinner, R.W.; Reingold, A.L.; Broome, C.V. Role of foods in sporadic listeriosis. I. Case-control study of dietary risk factors. The listeria study group. JAMA 1992, 267, 2041-2045. [CrossRef] [PubMed]

24. Ooi, S.T.; Lorber, B. Gastroenteritis due to listeria monocytogenes. Clin. Infect. Dis. 2005, 40, 1327-1332. [CrossRef] [PubMed]

25. Barbuddhe, S.B.; Chakraborty, T. Listeria as an enteroinvasive gastrointestinal pathogen. Curr. Top. Microbiol. Immunol. 2009, 337, 173-195. [PubMed]

26. Zhang, T.; Abel, S.; Abel Zur Wiesch, P.; Sasabe, J.; Davis, B.M.; Higgins, D.E.; Waldor, M.K. Deciphering the landscape of host barriers to listeria monocytogenes infection. Proc. Natl. Acad. Sci. USA 2017, 114, 6334-6339. [CrossRef] [PubMed] 
27. Melton-Witt, J.A.; Rafelski, S.M.; Portnoy, D.A.; Bakardjiev, A.I. Oral infection with signature-tagged listeria monocytogenes reveals organ-specific growth and dissemination routes in guinea pigs. Infect. Immun. 2012, 80, 720-732. [CrossRef] [PubMed]

28. Becattini, S.; Littmann, E.R.; Carter, R.A.; Kim, S.G.; Morjaria, S.M.; Ling, L.; Gyaltshen, Y.; Fontana, E.; Taur, Y.; Leiner, I.M.; et al. Commensal microbes provide first line defense against listeria monocytogenes infection. J. Exp. Med. 2017, 214, 1973-1989. [CrossRef] [PubMed]

29. Havell, E.A.; Beretich, G.R.; Carter, P.B. The mucosal phase of listeria infection. Immunobiology 1999, 201, 164-177. [CrossRef]

30. Bailey, J.S.; Fletcher, D.L.; Cox, N.A. Listeria monocytogenes colonization of broiler chickens. Poult. Sci. 1990, 69, 457-461. [CrossRef] [PubMed]

31. Nikitas, G.; Deschamps, C.; Disson, O.; Niault, T.; Cossart, P.; Lecuit, M. Transcytosis of listeria monocytogenes across the intestinal barrier upon specific targeting of goblet cell accessible e-cadherin. J. Exp. Med. 2011, 208, 2263-2277. [CrossRef] [PubMed]

32. Nishikawa, S.; Hirasue, M.; Miura, T.; Yamada, K.; Sasaki, S.; Nakane, A. Systemic dissemination by intrarectal infection with listeria monocytogenes in mice. Microbiol. Immunol. 1998, 42, 325-327. [CrossRef] [PubMed]

33. Marco, A.J.; Prats, N.; Ramos, J.A.; Briones, V.; Blanco, M.; Dominguez, L.; Domingo, M. A microbiological, histopathological and immunohistological study of the intragastric inoculation of listeria monocytogenes in mice. J. Comp. Pathol. 1992, 107, 1-9. [CrossRef]

34. Gahan, C.G.; Hill, C. Gastrointestinal phase of listeria monocytogenes infection. J. Appl. Microbiol. 2005, 98, 1345-1353. [CrossRef] [PubMed]

35. Toledo-Arana, A.; Dussurget, O.; Nikitas, G.; Sesto, N.; Guet-Revillet, H.; Balestrino, D.; Loh, E.; Gripenland, J.; Tiensuu, T.; Vaitkevicius, K.; et al. The listeria transcriptional landscape from saprophytism to virulence. Nature 2009, 459, 950-956. [CrossRef] [PubMed]

36. Jiang, L.; Olesen, I.; Andersen, T.; Fang, W.; Jespersen, L. Survival of listeria monocytogenes in simulated gastrointestinal system and transcriptional profiling of stress- and adhesion-related genes. Foodborne Pathog. Dis. 2010, 7, 267-274. [CrossRef] [PubMed]

37. Ho, J.L.; Shands, K.N.; Friedland, G.; Eckind, P.; Fraser, D.W. An outbreak of type 4b listeria monocytogenes infection involving patients from eight boston hospitals. Arch. Intern. Med. 1986, 146, 520-524. [CrossRef] [PubMed]

38. Schlech, W.F., 3rd; Chase, D.P.; Badley, A. A model of food-borne listeria monocytogenes infection in the sprague-dawley rat using gastric inoculation: Development and effect of gastric acidity on infective dose. Int. J. Food Microbiol. 1993, 18, 15-24. [CrossRef]

39. Brandl, K.; Plitas, G.; Schnabl, B.; DeMatteo, R.P.; Pamer, E.G. MyD88-mediated signals induce the bactericidal lectin regiii gamma and protect mice against intestinal listeria monocytogenes infection. J. Exp. Med. 2007, 204, 1891-1900. [CrossRef] [PubMed]

40. Saklani-Jusforgues, H.; Fontan, E.; Goossens, P.L. Effect of acid-adaptation on listeria monocytogenes survival and translocation in a murine intragastric infection model. FEMS Microbiol. Lett. 2000, 193, 155-159. [CrossRef] [PubMed]

41. Sue, D.; Fink, D.; Wiedmann, M.; Boor, K.J. Sigmab-dependent gene induction and expression in listeria monocytogenes during osmotic and acid stress conditions simulating the intestinal environment. Microbiology 2004, 150, 3843-3855. [CrossRef] [PubMed]

42. Barmpalia-Davis, I.M.; Geornaras, I.; Kendall, P.A.; Sofos, J.N. Differences in survival among 13 listeria monocytogenes strains in a dynamic model of the stomach and small intestine. Appl. Environ. Microbiol. 2008, 74, 5563-5567. [CrossRef] [PubMed]

43. Sleator, R.D.; Wouters, J.; Gahan, C.G.; Abee, T.; Hill, C. Analysis of the role of opuc, an osmolyte transport system, in salt tolerance and virulence potential of listeria monocytogenes. Appl. Environ. Microbiol. 2001, 67, 2692-2698. [CrossRef] [PubMed]

44. Buffie, C.G.; Bucci, V.; Stein, R.R.; McKenney, P.T.; Ling, L.; Gobourne, A.; No, D.; Liu, H.; Kinnebrew, M.; Viale, A.; et al. Precision microbiome reconstitution restores bile acid mediated resistance to clostridium difficile. Nature 2015, 517, 205-208. [CrossRef] [PubMed]

45. Gunn, J.S. Mechanisms of bacterial resistance and response to bile. Microb. Infect. Inst. Pasteur 2000, 2, 907-913. [CrossRef] 
46. Hofmann, A.F.; Eckmann, L. How bile acids confer gut mucosal protection against bacteria. Proc. Natl Acad. Sci. USA 2006, 103, 4333-4334. [CrossRef] [PubMed]

47. Hardy, J.; Francis, K.P.; DeBoer, M.; Chu, P.; Gibbs, K.; Contag, C.H. Extracellular replication of listeria monocytogenes in the murine gall bladder. Science 2004, 303, 851-853. [CrossRef] [PubMed]

48. Hardy, J.; Margolis, J.J.; Contag, C.H. Induced biliary excretion of listeria monocytogenes. Infect. Immun. 2006, 74, 1819-1827. [CrossRef] [PubMed]

49. Dussurget, O.; Cabanes, D.; Dehoux, P.; Lecuit, M.; Buchrieser, C.; Glaser, P.; Cossart, P.; European Listeria Genome, C. Listeria monocytogenes bile salt hydrolase is a prfa-regulated virulence factor involved in the intestinal and hepatic phases of listeriosis. Mol. Microbiol. 2002, 45, 1095-1106. [CrossRef] [PubMed]

50. Begley, M.; Gahan, C.G.M.; Hill, C. Bile stress response in listeria monocytogenes lo28: Adaptation, cross-protection, and identification of genetic loci involved in bile resistance. Appl. Environ. Microbiol. 2002, 68, 6005-6012. [CrossRef] [PubMed]

51. Begley, M.; Sleator, R.D.; Gahan, C.G.; Hill, C. Contribution of three bile-associated loci, bsh, pva, and btlb, to gastrointestinal persistence and bile tolerance of listeria monocytogenes. Infect. Immun. 2005, 73, 894-904. [CrossRef] [PubMed]

52. Sleator, R.D.; Wemekamp-Kamphuis, H.H.; Gahan, C.G.; Abee, T.; Hill, C. A prfa-regulated bile exclusion system (bile) is a novel virulence factor in listeria monocytogenes. Mol. Microbiol. 2005, 55, 1183-1195. [CrossRef] [PubMed]

53. Watson, D.; Sleator, R.D.; Casey, P.G.; Hill, C.; Gahan, C.G. Specific osmolyte transporters mediate bile tolerance in listeria monocytogenes. Infect. Immun. 2009, 77, 4895-4904. [CrossRef] [PubMed]

54. Travier, L.; Guadagnini, S.; Gouin, E.; Dufour, A.; Chenal-Francisque, V.; Cossart, P.; Olivo-Marin, J.C.; Ghigo, J.M.; Disson, O.; Lecuit, M. Acta promotes listeria monocytogenes aggregation, intestinal colonization and carriage. PLoS Pathog. 2013, 9, e1003131. [CrossRef] [PubMed]

55. Jaradat, Z.W.; Bhunia, A.K. Glucose and nutrient concentrations affect the expression of a 104-kilodalton listeria adhesion protein in listeria monocytogenes. Appl. Environ. Microbiol. 2002, 68, 4876-4883. [CrossRef] [PubMed]

56. Johansson, M.E.; Hansson, G.C. Immunological aspects of intestinal mucus and mucins. Nat. Rev. Immunol. 2016, 16, 639-649. [CrossRef] [PubMed]

57. Mariscotti, J.F.; Quereda, J.J.; Garcia-Del Portillo, F.; Pucciarelli, M.G. The listeria monocytogenes lpxtg surface protein LMO1413 is an invasin with capacity to bind mucin. Int. J. Med. Microbiol. 2014, 304, 393-404. [CrossRef] [PubMed]

58. Popowska, M.; Krawczyk-Balska, A.; Ostrowski, R.; Desvaux, M. Inll from listeria monocytogenes is involved in biofilm formation and adhesion to mucin. Front. Microbiol. 2017, 8, 660. [CrossRef] [PubMed]

59. Linden, S.K.; Bierne, H.; Sabet, C.; Png, C.W.; Florin, T.H.; McGuckin, M.A.; Cossart, P. Listeria monocytogenes internalins bind to the human intestinal mucin MUC2. Arch. Microbiol. 2008, 190, 101-104. [CrossRef] [PubMed]

60. Richter, J.F.; Gitter, A.H.; Gunzel, D.; Weiss, S.; Mohamed, W.; Chakraborty, T.; Fromm, M.; Schulzke, J.D. Listeriolysin O affects barrier function and induces chloride secretion in HT-29/B6 colon epithelial cells. Am. J. Physiol. Gastrointest. Liver Physiol. 2009, 296, G1350-G1359. [CrossRef] [PubMed]

61. Lievin-Le Moal, V.; Servin, A.L.; Coconnier-Polter, M.H. The increase in mucin exocytosis and the upregulation of muc genes encoding for membrane-bound mucins induced by the thiol-activated exotoxin listeriolysin $\mathrm{O}$ is a host cell defence response that inhibits the cell-entry of listeria monocytogenes. Cell. Microbiol. 2005, 7, 1035-1048. [CrossRef] [PubMed]

62. Coconnier, M.H.; Dlissi, E.; Robard, M.; Laboisse, C.L.; Gaillard, J.L.; Servin, A.L. Listeria monocytogenes stimulates mucus exocytosis in cultured human polarized mucosecreting intestinal cells through action of listeriolysin O. Infect. Immun. 1998, 66, 3673-3681. [PubMed]

63. Neudeck, B.L.; Loeb, J.M.; Faith, N.G.; Czuprynski, C.J. Intestinal P glycoprotein acts as a natural defense mechanism against listeria monocytogenes. Infect. Immun. 2004, 72, 3849-3854. [CrossRef] [PubMed]

64. Manohar, M.; Baumann, D.O.; Bos, N.A.; Cebra, J.J. Gut colonization of mice with acta-negative mutant of listeria monocytogenes can stimulate a humoral mucosal immune response. Infect. Immun. 2001, 69, 3542-3549. [CrossRef] [PubMed] 
65. Kinnebrew, M.A.; Buffie, C.G.; Diehl, G.E.; Zenewicz, L.A.; Leiner, I.; Hohl, T.M.; Flavell, R.A.; Littman, D.R.; Pamer, E.G. Interleukin 23 production by intestinal CD103(+)CD11b(+) dendritic cells in response to bacterial flagellin enhances mucosal innate immune defense. Immunity 2012, 36, 276-287. [CrossRef] [PubMed]

66. Mukherjee, S.; Zheng, H.; Derebe, M.G.; Callenberg, K.M.; Partch, C.L.; Rollins, D.; Propheter, D.C.; Rizo, J.; Grabe, M.; Jiang, Q.X.; et al. Antibacterial membrane attack by a pore-forming intestinal C-type lectin. Nature 2014, 505, 103-107. [CrossRef] [PubMed]

67. Kobayashi, K.S.; Chamaillard, M.; Ogura, Y.; Henegariu, O.; Inohara, N.; Nunez, G.; Flavell, R.A. NOD2-dependent regulation of innate and adaptive immunity in the intestinal tract. Science 2005, 307, 731-734. [CrossRef] [PubMed]

68. Veldhuizen, E.J.; Rijnders, M.; Claassen, E.A.; van Dijk, A.; Haagsman, H.P. Porcine beta-defensin 2 displays broad antimicrobial activity against pathogenic intestinal bacteria. Mol. Immunol. 2008, 45, 386-394. [CrossRef] [PubMed]

69. Harwig, S.S.; Tan, L.; Qu, X.D.; Cho, Y.; Eisenhauer, P.B.; Lehrer, R.I. Bactericidal properties of murine intestinal phospholipase A2. J. Clin. Investig. 1995, 95, 603-610. [CrossRef] [PubMed]

70. Menard, S.; Forster, V.; Lotz, M.; Gutle, D.; Duerr, C.U.; Gallo, R.L.; Henriques-Normark, B.; Putsep, K.; Andersson, M.; Glocker, E.O.; et al. Developmental switch of intestinal antimicrobial peptide expression. J. Exp. Med. 2008, 205, 183-193. [CrossRef] [PubMed]

71. Meyer-Hoffert, U.; Hornef, M.W.; Henriques-Normark, B.; Axelsson, L.G.; Midtvedt, T.; Putsep, K.; Andersson, M. Secreted enteric antimicrobial activity localises to the mucus surface layer. Gut 2008, 57, 764-771. [CrossRef] [PubMed]

72. Johansson, M.E.; Jakobsson, H.E.; Holmen-Larsson, J.; Schutte, A.; Ermund, A.; Rodriguez-Pineiro, A.M.; Arike, L.; Wising, C.; Svensson, F.; Backhed, F.; et al. Normalization of host intestinal mucus layers requires long-term microbial colonization. Cell Host Microbe 2015, 18, 582-592. [CrossRef] [PubMed]

73. Brandl, K.; Plitas, G.; Mihu, C.N.; Ubeda, C.; Jia, T.; Fleisher, M.; Schnabl, B.; DeMatteo, R.P.; Pamer, E.G. Vancomycin-resistant enterococci exploit antibiotic-induced innate immune deficits. Nature 2008, 455, 804-807. [CrossRef] [PubMed]

74. Long, S.L.; Gahan, C.G.M.; Joyce, S.A. Interactions between gut bacteria and bile in health and disease. Mol. Aspects Med. 2017, 56, 54-65. [CrossRef] [PubMed]

75. Khosravi, A.; Yanez, A.; Price, J.G.; Chow, A.; Merad, M.; Goodridge, H.S.; Mazmanian, S.K. Gut microbiota promote hematopoiesis to control bacterial infection. Cell Host Microbe 2014, 15, 374-381. [CrossRef] [PubMed]

76. Abt, M.C.; Osborne, L.C.; Monticelli, L.A.; Doering, T.A.; Alenghat, T.; Sonnenberg, G.F.; Paley, M.A.; Antenus, M.; Williams, K.L.; Erikson, J.; et al. Commensal bacteria calibrate the activation threshold of innate antiviral immunity. Immunity 2012, 37, 158-170. [CrossRef] [PubMed]

77. Becattini, S.; Taur, Y.; Pamer, E.G. Antibiotic-induced changes in the intestinal microbiota and disease. Trends Mol. Med. 2016, 22, 458-478. [CrossRef] [PubMed]

78. Zhang, Q.; Pan, Y.; Yan, R.; Zeng, B.; Wang, H.; Zhang, X.; Li, W.; Wei, H.; Liu, Z. Commensal bacteria direct selective cargo sorting to promote symbiosis. Nat. Immunol. 2015, 16, 918-926. [CrossRef] [PubMed]

79. Cabinian, A.; Sinsimer, D.; Tang, M.; Jang, Y.; Choi, B.; Laouar, Y.; Laouar, A. Gut symbiotic microbes imprint intestinal immune cells with the innate receptor SLAMF4 which contributes to gut immune protection against enteric pathogens. Gut 2017. [CrossRef] [PubMed]

80. Archambaud, C.; Nahori, M.A.; Soubigou, G.; Becavin, C.; Laval, L.; Lechat, P.; Smokvina, T.; Langella, P.; Lecuit, M.; Cossart, P. Impact of lactobacilli on orally acquired listeriosis. Proc. Natl. Acad. Sci. USA 2012, 109, 16684-16689. [CrossRef] [PubMed]

81. Corr, S.C.; Gahan, C.G.; Hill, C. Impact of selected lactobacillus and bifidobacterium species on listeria monocytogenes infection and the mucosal immune response. FEMS Immunol. Med. Microbiol. 2007, 50, 380-388. [CrossRef] [PubMed]

82. Pamer, E.G. Resurrecting the intestinal microbiota to combat antibiotic-resistant pathogens. Science 2016, 352, 535-538. [CrossRef] [PubMed]

83. Bohnhoff, M.; Drake, B.L.; Miller, C.P. Effect of streptomycin on susceptibility of intestinal tract to experimental salmonella infection. Proc. Soc. Exp. Biol. Med. 1954, 86, 132-137. [CrossRef] [PubMed] 
84. Lewis, B.B.; Buffie, C.G.; Carter, R.A.; Leiner, I.; Toussaint, N.C.; Miller, L.C.; Gobourne, A.; Ling, L.; Pamer, E.G. Loss of microbiota-mediated colonization resistance to clostridium difficile infection with oral vancomycin compared with metronidazole. J. Infect. Dis. 2015, 212, 1656-1665. [CrossRef] [PubMed]

85. Zachar, Z.; Savage, D.C. Microbial interference and colonization of the murine gastrointestinal tract by listeria monocytogenes. Infect. Immun. 1979, 23, 168-174. [PubMed]

86. Czuprynski, C.J.; Balish, E. Pathogenesis of listeria monocytogenes for gnotobiotic rats. Infect. Immun. 1981, 32, 323-331. [PubMed]

87. Round, J.L.; Mazmanian, S.K. The gut microbiota shapes intestinal immune responses during health and disease. Nat. Rev. Immunol. 2009, 9, 313-323. [CrossRef] [PubMed]

88. Schlech, W.F., 3rd. An animal model of foodborne listeria monocytogenes virulence: Effect of alterations in local and systemic immunity on invasive infection. Clin. Investig. Med. 1993, 16, 219-225.

89. Okamoto, M.; Nakane, A.; Minagawa, T. Host resistance to an intragastric infection with listeria monocytogenes in mice depends on cellular immunity and intestinal bacterial flora. Infect. Immun. 1994, 62, 3080-3085. [PubMed]

90. Vijayakumar, P.P.; Muriana, P.M. A microplate growth inhibition assay for screening bacteriocins against listeria monocytogenes to differentiate their mode-of-action. Biomolecules 2015, 5, 1178-1194. [CrossRef] [PubMed]

91. Zhu, W.M.; Liu, W.; Wu, D.Q. Isolation and characterization of a new bacteriocin from lactobacillus gasseri kt7. J. Appl. Microbiol. 2000, 88, 877-886. [CrossRef] [PubMed]

92. Allende, A.; Martinez, B.; Selma, V.; Gil, M.I.; Suarez, J.E.; Rodriguez, A. Growth and bacteriocin production by lactic acid bacteria in vegetable broth and their effectiveness at reducing listeria monocytogenes in vitro and in fresh-cut lettuce. Food Microbiol. 2007, 24, 759-766. [CrossRef] [PubMed]

93. Gibson, G.R.; Wang, X. Regulatory effects of bifidobacteria on the growth of other colonic bacteria. J. Appl. Bacteriol. 1994, 77, 412-420. [CrossRef] [PubMed]

94. Yang, D.; Wu, X.; Yu, X.; He, L.; Shah, N.P.; Xu, F. Mutual growth-promoting effect between bifidobacterium bifidum wbbi03 and listeria monocytogenes cmcc 54001. J. Dairy Sci. 2017, 100, 3448-3462. [CrossRef] [PubMed]

95. Odamaki, T.; Kato, K.; Sugahara, H.; Hashikura, N.; Takahashi, S.; Xiao, J.Z.; Abe, F.; Osawa, R. Age-related changes in gut microbiota composition from newborn to centenarian: A cross-sectional study. BMC Microbiol. 2016, 16, 90. [CrossRef] [PubMed]

96. Yatsunenko, T.; Rey, F.E.; Manary, M.J.; Trehan, I.; Dominguez-Bello, M.G.; Contreras, M.; Magris, M.; Hidalgo, G.; Baldassano, R.N.; Anokhin, A.P.; et al. Human gut microbiome viewed across age and geography. Nature 2012, 486, 222-227. [CrossRef] [PubMed]

97. Koren, O.; Goodrich, J.K.; Cullender, T.C.; Spor, A.; Laitinen, K.; Backhed, H.K.; Gonzalez, A.; Werner, J.J.; Angenent, L.T.; Knight, R.; et al. Host remodeling of the gut microbiome and metabolic changes during pregnancy. Cell 2012, 150, 470-480. [CrossRef] [PubMed]

98. Lozupone, C.A.; Stombaugh, J.I.; Gordon, J.I.; Jansson, J.K.; Knight, R. Diversity, stability and resilience of the human gut microbiota. Nature 2012, 489, 220-230. [CrossRef] [PubMed]

99. Menudier, A.; Bosgiraud, C.; Nicolas, J.A. Virulence of listeria monocytogenes in pregnant mice. Pathol. Biol. 1994, 42, 510-515. [PubMed]

100. Kerr, A.K.; Farrar, A.M.; Waddell, L.A.; Wilkins, W.; Wilhelm, B.J.; Bucher, O.; Wills, R.W.; Bailey, R.H.; Varga, C.; McEwen, S.A.; et al. A systematic review-meta-analysis and meta-regression on the effect of selected competitive exclusion products on salmonella spp. Prevalence and concentration in broiler chickens. Prev. Vet. Med. 2013, 111, 112-125. [CrossRef] [PubMed]

101. Wagner, R.D.; Holland, M.; Cerniglia, C.E. An in vitro assay to evaluate competitive exclusion products for poultry. J. Food Prot. 2002, 65, 746-751. [CrossRef] [PubMed]

102. Hume, M.E.; Byrd, J.A.; Stanker, L.H.; Ziprin, R.L. Reduction of caecal listeria monocytogenes in leghorn chicks following treatment with a competitive exclusion culture (preempt). Lett. Appl. Microbiol. 1998, 26, 432-436. [CrossRef] [PubMed]

103. Cotter, P.D.; Hill, C.; Ross, R.P. Bacteriocins: Developing innate immunity for food. Nat. Rev. Microbiol. 2005, 3, 777-788. [CrossRef] [PubMed]

104. Turgis, M.; Vu, K.D.; Lacroix, M. Partial characterization of bacteriocins produced by two new enterococcus faecium isolated from human intestine. Probiotics Antimicrob. Proteins 2013, 5, 110-120. [CrossRef] [PubMed] 
105. Lakshminarayanan, B.; Guinane, C.M.; O'Connor, P.M.; Coakley, M.; Hill, C.; Stanton, C.; O'Toole, P.W.; Ross, R.P. Isolation and characterization of bacteriocin-producing bacteria from the intestinal microbiota of elderly irish subjects. J. Appl. Microbiol. 2013, 114, 886-898. [CrossRef] [PubMed]

106. Millette, M.; Dupont, C.; Shareck, F.; Ruiz, M.T.; Archambault, D.; Lacroix, M. Purification and identification of the pediocin produced by pediococcus acidilactici MM33, a new human intestinal strain. J. Appl. Microbiol. 2008, 104, 269-275. [CrossRef] [PubMed]

107. Le Blay, G.; Hammami, R.; Lacroix, C.; Fliss, I. Stability and inhibitory activity of pediocin pa-1 against listeria sp. In simulated physiological conditions of the human terminal ileum. Probiotics Antimicrob. Proteins 2012, 4, 250-258. [CrossRef] [PubMed]

108. Guinane, C.M.; Cotter, P.D.; Hill, C.; Ross, R.P. Microbial solutions to microbial problems; lactococcal bacteriocins for the control of undesirable biota in food. J. Appl. Microbiol. 2005, 98, 1316-1325. [CrossRef] [PubMed]

109. Campion, A.; Casey, P.G.; Field, D.; Cotter, P.D.; Hill, C.; Ross, R.P. In vivo activity of nisin a and nisin v against listeria monocytogenes in mice. BMC Microbiol. 2013, 13, 23. [CrossRef] [PubMed]

110. Field, D.; Quigley, L.; O'Connor, P.M.; Rea, M.C.; Daly, K.; Cotter, P.D.; Hill, C.; Ross, R.P. Studies with bioengineered nisin peptides highlight the broad-spectrum potency of nisin v. Microb. Biotechnol. 2010, 3, 473-486. [CrossRef] [PubMed]

111. Benkerroum, N.; Sandine, W.E. Inhibitory action of nisin against listeria monocytogenes. J. Dairy Sci. 1988, 71, 3237-3245. [CrossRef]

112. Collins, F.W.; O'Connor, P.M.; O'Sullivan, O.; Rea, M.C.; Hill, C.; Ross, R.P. Formicin-A novel broad-spectrum two-component lantibiotic produced by bacillus paralicheniformis APC 1576. Microbiology 2016, 162, 1662-1671. [CrossRef] [PubMed]

113. Corr, S.C.; Li, Y.; Riedel, C.U.; O’Toole, P.W.; Hill, C.; Gahan, C.G. Bacteriocin production as a mechanism for the antiinfective activity of lactobacillus salivarius ucc118. Proc. Natl. Acad. Sci. USA 2007, 104, 7617-7621. [CrossRef] [PubMed]

114. Altenhoefer, A.; Oswald, S.; Sonnenborn, U.; Enders, C.; Schulze, J.; Hacker, J.; Oelschlaeger, T.A. The probioticescherichia colistrain nissle 1917 interferes with invasion of human intestinal epithelial cells by different enteroinvasive bacterial pathogens. FEMS Immunol. Med. Microbiol. 2004, 40, 223-229. [CrossRef]

115. Blom, H.; Nerbrink, E.; Dainty, R.; Hagtvedt, T.; Borch, E.; Nissen, H.; Nesbakken, T. Addition of 2.5\% lactate and $0.25 \%$ acetate controls growth of listeria monocytogenes in vacuum-packed, sensory-acceptable servelat sausage and cooked ham stored at 4 degrees C. Int. J. Food Microbiol. 1997, 38, 71-76. [CrossRef]

116. Hinton, A., Jr.; Hume, M.E. Research note: In vitro inhibition of listeria monocytogenes growth by veillonellae cultures grown on tartrate media. J. Appl. Microbiol. 1997, 82, 780-782. [CrossRef] [PubMed]

117. Aoki, S.K.; Diner, E.J.; de Roodenbeke, C.T.; Burgess, B.R.; Poole, S.J.; Braaten, B.A.; Jones, A.M.; Webb, J.S.; Hayes, C.S.; Cotter, P.A.; et al. A widespread family of polymorphic contact-dependent toxin delivery systems in bacteria. Nature 2010, 468, 439-442. [CrossRef] [PubMed]

118. Aoki, S.K.; Pamma, R.; Hernday, A.D.; Bickham, J.E.; Braaten, B.A.; Low, D.A. Contact-dependent inhibition of growth in escherichia coli. Science 2005, 309, 1245-1248. [CrossRef] [PubMed]

119. Saraoui, T.; Fall, P.A.; Leroi, F.; Antignac, J.P.; Chereau, S.; Pilet, M.F. Inhibition mechanism of listeria monocytogenes by a bioprotective bacteria lactococcus piscium cncm i-4031. Food Microbiol. 2016, 53, 70-78. [CrossRef] [PubMed]

120. Zilelidou, E.A.; Rychli, K.; Manthou, E.; Ciolacu, L.; Wagner, M.; Skandamis, P.N. Highly invasive listeria monocytogenes strains have growth and invasion advantages in strain competition. PLOS ONE 2015, 10, e0141617. [CrossRef] [PubMed]

121. Whitney, J.C.; Peterson, S.B.; Kim, J.; Pazos, M.; Verster, A.J.; Radey, M.C.; Kulasekara, H.D.; Ching, M.Q.; Bullen, N.P.; Bryant, D.; et al. A broadly distributed toxin family mediates contact-dependent antagonism between gram-positive bacteria. Elife 2017, 6, e26938. [CrossRef] [PubMed]

122. Quereda, J.J.; Dussurget, O.; Nahori, M.A.; Ghozlane, A.; Volant, S.; Dillies, M.A.; Regnault, B.; Kennedy, S.; Mondot, S.; Villoing, B.; et al. Bacteriocin from epidemic listeria strains alters the host intestinal microbiota to favor infection. Proc. Natl. Acad. Sci. USA 2016, 113, 5706-5711. [CrossRef] [PubMed]

(C) 2017 by the authors. Licensee MDPI, Basel, Switzerland. This article is an open access article distributed under the terms and conditions of the Creative Commons Attribution (CC BY) license (http://creativecommons.org/licenses/by/4.0/). 